\title{
Ritual plants used by the Manobo tribe of Surigao del Sur, Philippines
}

\author{
JAKE KEITH ADRIAN M. JAMERA ${ }^{1}$, MUHMIN MICHAEL E. MANTING ${ }^{1}$, MARK LLOYD G. DAPAR ${ }^{2, \bullet}$ \\ ${ }^{1}$ Department of Biological Sciences, College of Science and Mathematics, Mindanao State University-Iligan Institute of Technology, 9200 Iligan City, \\ Lanao del Norte, Philippines \\ ${ }^{2}$ The Graduate School and Research Center for the Natural and Applied Sciences, University of Santo Tomas, España Boulevard, 1015 Manila, \\ Philippines. "email: marklloyd.dapar.gs@ust.edu.ph
}

Manuscript received: 11 August 2020. Revision accepted: 12 September 2020.

\begin{abstract}
Jamera JKAM, Manting MME, Dapar MLG. 2020. Ritual plants used by the Manobo tribe of Surigao del Sur, Philippines. Asian J Ethnobiol 3: 41-50. Manobo tribe is culturally rich in traditional practices, medicinal uses, diversity, and traditional knowledge based on their community plant resources. They dwell in hinterlands and mountainous regions in the southern part of the Philippines and live an intricate life dependent on agriculture and forest plants. Traditional ecological knowledge and beliefs of indigenous peoples play an essential role in biodiversity conservation. This study seeks to investigate the use of ritual plants of the Manobo tribe in Hinapuyan, Carmen and Cabangahan, Cantilan, Surigao del Sur, and to identify the availability of ritual plants being used. Plant information with the local name, plant parts used, methods of preparation, ritual uses, and the Cultural Importance Index (CI) were quantified. This study documented a total of 12 traditional rituals associated with ritual plants. The five identified plant species are used in tribal rituals belonging to four different families: Arecaceae, Piperaceae, Poaceae, and Solanaceae. Arecaceae includes two species, while one species represents each of the families. Ritual plants with the highest CI were Areca catechu L., Piper betle L., and Nicotiana tabacum L. Manobo ritual plants have a symbolic meaning and rational function. This study is the first documentation of ritual plants presenting traditional ecological knowledge and cultural beliefs that must be saved to maintain biological diversity. The tribe cultivated some ritual plants and their wild plant collection in the village yard. These ritual plants are conserved and protected by the Manobo community. More investigations are recommended on the ritual plants used among diverse ethnolinguistic groups in the Philippines and other countries.
\end{abstract}

Keywords: Beliefs and Practices, cultural importance index, ethnobotany, Manobo, ritual plants

\section{INTRODUCTION}

Plants are used in many ways by various cultural communities generally for healthcare practices and medicinal uses in the Philippines (Dapar and Demayo 2017; Dapar et al. 2018; Abdulaziz et al. 2019; Añides et al. 2019; Dela Peña et al. 2019; Nadayag et al. 2019; Uy et al. 2019). Apart from medicinal uses and therapy, plants are also utilized in rituals or magical purposes (Abbink 1995; Quiroz et al. 2016). Ritual serves as a traditional practice, which marks the cultural identity of a particular indigenous group through prayers and worship to their deities, gods, and goddesses for protection, thanksgiving, and betterment of human life. Rituals are part of worshipping gods and goddesses on various occasions, from birth to mourning death (Sharma and Pegu 2011). Ritual plants have symbolic meaning and rational functions in diverse ethnicity, religions, and beliefs of people and indigenous groups (Hariyadi and Ticktin 2012; Iskandar and Iskandar 2017; Erawan et al. 2018).

In the Philippines, the largest indigenous groups of the Manobo tribe practice rituals as an integral part of their culture. Ritual observations are the significant practice of Manobo culture in asking permission and approval from their deities in any activities in their ancestral lands and indigenous territories (Dapar et al. 2020b, 2020c). Agusan Manobo healers practice ritual prayers to increase the healing potential of their herbal medicines and some other purposes (Dapar et al. 2020b). Agusan Manobo often passes their traditional system to the next generation through verbal communication (Dapar et al. 2020b; 2020c). Manobo tribe is one of the largest indigenous groups of people on the island of Mindanao, Philippines, including the tribe of Surigao Manobo in the province of Surigao. The word Manobo came from "mansuba," meaning man, and "suba," meaning river (Felix 2004), which means river people (Dapar et al. 2020a). Manobo settlers occupied Mindanao's mountain regions and hinterlands in the northernmost part along rivers, valleys, and swamps. Manobo people are concentrated in Agusan, Bukidnon, Cotabato, Davao, Misamis Oriental, and Surigao del Sur (De Jong 2010).

Most indigenous peoples (IPs) use plants for their culture, especially in performing rituals. Indigenous Cultural Communities/Indigenous Peoples (ICCs/IPs) performing rituals typically use plants associated with their beliefs and practices. Various plant parts or whole plants can be used for rituals and ceremonies. Conservation strategies are efficient with the combined information in consideration and understanding of ritual practices of tribal communities (Geng et al., 2017). Ritual beliefs of the indigenous people are essential information in understanding the local community practices and conservation of biodiversity. Some of the problems that the indigenous people face nowadays are the biodiversity crisis and the possible loss of indigenous knowledge (Dapar et al. 
2020d, 2020e). Unlike the numerous healers from previous generations, few plant experts (tribal healers) remained among the Manobo communities. Hence, this situation calls to save indigenous knowledge and traditional culture to increase awareness on the conservation of indigenous ritual plants.

With this realization, this study seeks information about ritual plants used by the Surigao Manobo for a specific cultural purpose and traditional rite of passage from childhood to adulthood, social preparations, and other occasions.

\section{MATERIALS AND METHODS}

\section{Study area}

The fieldwork was conducted in the selected barangays (villages), namely Hinapuyan in Carmen and Cabangahan in Cantilan of Surigao del Sur, as shown in Figure 1. Carmen is a fifth-class municipality in the province of Surigao del Sur with coordinates $9^{\circ} 12^{\prime} 6.48^{\prime \prime} \mathrm{N}, 125^{\circ}$ 58 '50.16" E. It is politically subdivided into nine barangays which include barangay Hinapuyan. Cantilan is another municipality of Surigao del Sur, considered the "Cradle of
Towns" in the province located in the coordinates $9^{\circ}$ 16 '58.08" N, $125^{\circ} 56 ’ 31.92$ " E.

\section{Field survey}

This study was initiated by securing free prior informed consent of the Manobo community before conducting a field survey. Key informants were interviewed together with the Manobo healers and tribal chieftain. Data were collected through a questionnaire using Bradacs (2008) from Hinapuyan, Carmen, and Cabangahan, Cantilan in Surigao del Sur. The obtained information was compared and cross-linked to ascertain their validity and integrity. Photographs of plants were taken for identification with taxonomic keys and verified using the updated Co's Digital Flora of the Philippines (Pelser et al. 2011 onwards).

\section{Data analysis}

Cultural Importance Index (CI) was applied to determine the cultural significance of plant species in each locality. It is calculated using this formula $\mathrm{CI}=(\Sigma \mathrm{UR}) / \mathrm{N}$, as the summation of the use report (UR) in every use category mentioned for a species in the locality divided by the number of participants $(\mathrm{N})$ in that locality (Tardío and Pardo-de-Santayana 2008).

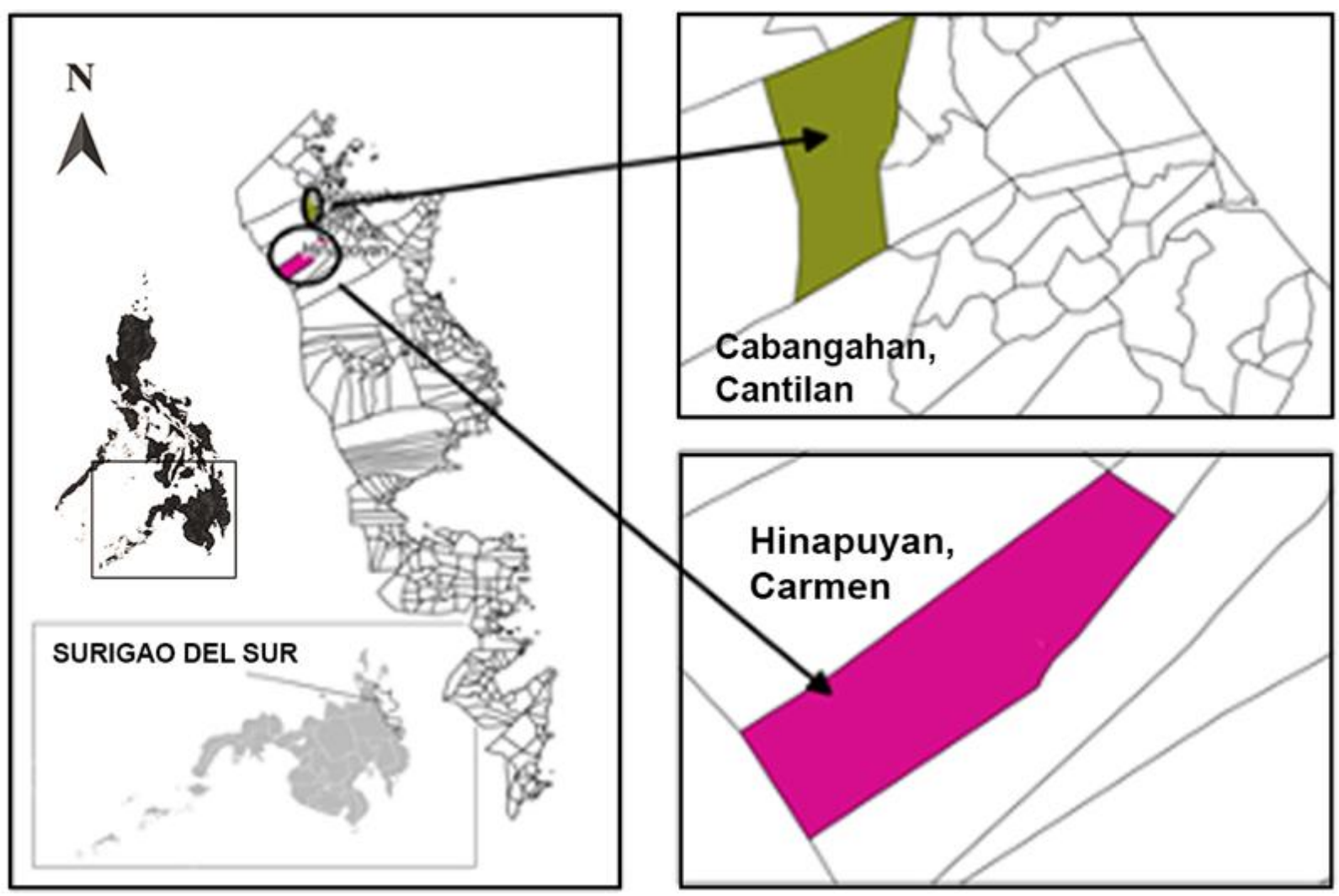

Figure 1. Location map of Bayugan City (middle and right, outlined in red), Agusan del Sur (left, outlined in black), Philippines 


\section{RESULTS AND DISCUSSION}

\section{Manobo rituals plants}

A total of five plant species were used in 12 Manobo rituals belonging to four different families, namely Arecaceae, Piperaceae, Poaceae, and Solanaceae (Table 1). Results showed that three species have the highest CI values of 1.0, namely Areca catechu L., Piper betle L., and Nicotiana tabacum L.; and followed by Cocos nucifera L. (0.92) and Oryza sativa L. (0.50). Plant information with its local name, plant part used, preparation method, ritual uses, and Cultural Importance Index (CI) were presented. Manobo terms and rituals are summarized in Table 2.
Table 3 presents the different rituals corresponding to the plant families and the number of ritual plants. Ritual for the sick "Binuyahan" depending on how critically ill the person is together with three other rituals known as "Panawagtawag" ritual for harvest, "Pagmaan" ritual for building a house, and "Tagun-un" ritual for baptism. These rituals need three plant families: Arecaceae, Piperaceae, and Solanaceae. The ritual for repentance "Tampoda," the ritual for the wedding "Kumbiti," the ritual for forgiveness "Boneh," the ritual for the full-moon festival "Kahimonan," the ritual for birth "Limpasan," and ritual practice for burial "Uyagdok" utilize of four plant families, namely Arecaceae, Piperaceae, Poaceae, and Solanaceae.

Table 1. Ritual plants used by Manobo tribe in Hinapuyan, Carmen and Cabangahan, Cantilan Surigao del Sur, Philippines

\begin{tabular}{|c|c|c|c|c|c|c|c|c|}
\hline $\begin{array}{l}\text { Family and } \\
\text { scientific } \\
\text { name }\end{array}$ & $\begin{array}{l}\text { Common } \\
\text { name }\end{array}$ & $\begin{array}{l}\text { Manobo } \\
\text { name }\end{array}$ & $\begin{array}{l}\text { Plant } \\
\text { part } \\
\text { used }\end{array}$ & $\begin{array}{l}\text { Method of } \\
\text { preparation }\end{array}$ & $\begin{array}{l}\text { Habit of } \\
\text { growth }\end{array}$ & $\begin{array}{l}\text { Availability } \\
\text { of the plant }\end{array}$ & $\begin{array}{l}\text { Source of } \\
\text { collection }\end{array}$ & $\begin{array}{l}\text { Cultural } \\
\text { importance } \\
\text { value }\end{array}$ \\
\hline $\begin{array}{l}\text { Arecaceae } \\
\text { Areca catechu } \\
\text { L. }\end{array}$ & $\begin{array}{l}\text { Nut Palm; } \\
\text { Bujo }\end{array}$ & $\begin{array}{l}\text { Mama/ } \\
\text { Bunga }\end{array}$ & Fruit & $\begin{array}{l}\text { Wrapped } \\
\text { together with } \\
\text { "bujo" leaves }\end{array}$ & Palm & Rare & Wild & 1.00 \\
\hline $\begin{array}{l}\text { Cocos } \\
\text { nucifera } \mathrm{L} .\end{array}$ & Coconut & Lubi & $\begin{array}{l}\text { Young } \\
\text { Leaves }\end{array}$ & $\begin{array}{l}\text { Obtained } \\
\text { directly }\end{array}$ & Palm & Common & $\begin{array}{l}\text { Cultivated } \\
\text { or Wild }\end{array}$ & 0.92 \\
\hline $\begin{array}{l}\text { Piperaceae } \\
\text { Piper betle L. }\end{array}$ & Betel & Bujo & Leaves & $\begin{array}{l}\text { Wrapped } \\
\text { together with } \\
\text { "mama" fruit }\end{array}$ & Vine & Rare & Wild & 1.00 \\
\hline $\begin{array}{l}\text { Poaceae } \\
\text { Oryza sativa } \\
\text { L. }\end{array}$ & Rice & Bugas & $\begin{array}{l}\text { Fruit or } \\
\text { Seed }\end{array}$ & $\begin{array}{l}\text { Cooked or } \\
\text { uncooked }\end{array}$ & Grass & Common & Cultivated & 0.50 \\
\hline $\begin{array}{l}\text { Solanaceae } \\
\text { Nicotiana } \\
\text { tabacum L. }\end{array}$ & Tobacco & Tabako & Leaves & Dried & Herb & Rare & Wild & 1.00 \\
\hline
\end{tabular}

Table 2. Definition of local terms

\begin{tabular}{ll}
\hline Manobo terms and rituals & Meaning of terms and rituals \\
\hline Baylan & Manobo tribe healer \\
Boneh & Ritual for forgiveness \\
Gilamat & Deceived by the illusion or charmed by the spirits \\
Kahimonan & Manobo term for their full-moon festival \\
Kumbiti & Ritual term for wedding \\
Lala & Extremely severe sickness \\
Limpasan & Ritual term for birth \\
Mahal & Severe sickness \\
Mamaid & Ritual for asking permission to enter the forest \\
Pagmaan & Ritual term for house building \\
Pamebag & Ritual for barrier \\
Panawagtawag & Ritual term for thanksgiving for the harvest \\
Tagun-un & Ritual for baptism \\
Tampoda & Ritual term for repentance \\
Uyagdok & Ritual term for burial \\
\hline
\end{tabular}


Table 3. Different rituals and ritual plants used

\begin{tabular}{|c|c|c|c|}
\hline Ritual description & Local ritual name & Family & Scientific name \\
\hline Ritual for healing & Binuyahan & $\begin{array}{l}\text { Arecaceae } \\
\text { Piperaceae } \\
\text { Solanaceae }\end{array}$ & $\begin{array}{l}\text { Areca catechu } \mathrm{L} ., \text { Cocos nucifera } \mathrm{L} \text {. } \\
\text { Piper betle } \mathrm{L} . \\
\text { Nicotiana tabacum } \mathrm{L} .\end{array}$ \\
\hline Ritual for repentance & Tampoda & $\begin{array}{l}\text { Arecaceae } \\
\text { Piperaceae } \\
\text { Solanaceae } \\
\text { Poaceae }\end{array}$ & $\begin{array}{l}\text { Areca catechu } \mathrm{L} ., \text { Cocos nucifera } \mathrm{L} \text {. } \\
\text { Piper betle } \mathrm{L} . \\
\text { Nicotiana tabacum } \mathrm{L} . \\
\text { Oryza sativa } \mathrm{L} .\end{array}$ \\
\hline Ritual for wedding & Kumbiti & $\begin{array}{l}\text { Arecaceae } \\
\text { Piperaceae } \\
\text { Solanaceae } \\
\text { Poaceae }\end{array}$ & $\begin{array}{l}\text { Areca catechu } \mathrm{L} ., \text { Cocos nucifera } \mathrm{L} \text {. } \\
\text { Piper betle } \mathrm{L} . \\
\text { Nicotiana tabacum } \mathrm{L} . \\
\text { Oryza sativa } \mathrm{L} .\end{array}$ \\
\hline $\begin{array}{l}\text { Asking permission to enter } \\
\text { the forest }\end{array}$ & Mamaid & $\begin{array}{l}\text { Arecaceae } \\
\text { Piperaceae } \\
\text { Solanaceae } \\
\text { Poaceae }\end{array}$ & $\begin{array}{l}\text { Areca catechu } \mathrm{L} ., \text { Cocos nucifera } \mathrm{L} \text {. } \\
\text { Piper betle } \mathrm{L} . \\
\text { Nicotiana tabacum } \mathrm{L} . \\
\text { Oryza sativa } \mathrm{L} .\end{array}$ \\
\hline Thanksgiving for the harvest & Panawagtawag & $\begin{array}{l}\text { Arecaceae } \\
\text { Piperaceae } \\
\text { Solanaceae }\end{array}$ & $\begin{array}{l}\text { Areca catechu } \mathrm{L} ., \text { Cocos nucifera } \mathrm{L} \text {. } \\
\text { Piper betle } \mathrm{L} \text {. } \\
\text { Nicotiana tabacum } \mathrm{L} \text {. }\end{array}$ \\
\hline House building & Pagmaan & $\begin{array}{l}\text { Arecaceae } \\
\text { Piperaceae } \\
\text { Solanaceae } \\
\text { Poaceae }\end{array}$ & $\begin{array}{l}\text { Areca catechu } \mathrm{L} ., \text { Cocos nucifera } \mathrm{L} \text {. } \\
\text { Piper betle } \mathrm{L} . \\
\text { Nicotiana tabacum } \mathrm{L} . \\
\text { Oryza sativa } \mathrm{L} .\end{array}$ \\
\hline Ritual for barrier & Pamebag & $\begin{array}{l}\text { Arecaceae } \\
\text { Piperaceae } \\
\text { Solanaceae }\end{array}$ & $\begin{array}{l}\text { Areca catechu } \mathrm{L} . \\
\text { Piper betle } \mathrm{L} . \\
\text { Nicotiana tabacum } \mathrm{L} .\end{array}$ \\
\hline Ritual for baptism & Tagun-un & $\begin{array}{l}\text { Arecaceae } \\
\text { Piperaceae } \\
\text { Solanaceae }\end{array}$ & $\begin{array}{l}\text { Areca catechu } \mathrm{L} ., \text { Cocos nucifera } \mathrm{L} \text {. } \\
\text { Piper betle } \mathrm{L} . \\
\text { Nicotiana tabacum } \mathrm{L} .\end{array}$ \\
\hline Ritual for forgiveness & Boneh & $\begin{array}{l}\text { Arecaceae } \\
\text { Piperaceae } \\
\text { Solanaceae } \\
\text { Poaceae }\end{array}$ & $\begin{array}{l}\text { Areca catechu } \mathrm{L} ., \text { Cocos nucifera } \mathrm{L} \text {. } \\
\text { Piper betle } \mathrm{L} . \\
\text { Nicotiana tabacum } \mathrm{L} . \\
\text { Oryza sativa } \mathrm{L} .\end{array}$ \\
\hline Full moon festival & Kahimunan & $\begin{array}{l}\text { Arecaceae } \\
\text { Piperaceae } \\
\text { Solanaceae } \\
\text { Poaceae }\end{array}$ & $\begin{array}{l}\text { Areca catechu } \mathrm{L} ., \text { Cocos nucifera } \mathrm{L} \text {. } \\
\text { Piper betle } \mathrm{L} . \\
\text { Nicotiana tabacum } \mathrm{L} . \\
\text { Oryza sativa } \mathrm{L} .\end{array}$ \\
\hline Ritual for birth & Limpasan & $\begin{array}{l}\text { Arecaceae } \\
\text { Piperaceae } \\
\text { Solanaceae }\end{array}$ & $\begin{array}{l}\text { Areca catechu } \mathrm{L} ., \text { Cocos nucifera } \mathrm{L} \text {. } \\
\text { Piper betle } \mathrm{L} . \\
\text { Nicotiana tabacum } \mathrm{L} .\end{array}$ \\
\hline Ritual for burial & Uyagdok & $\begin{array}{l}\text { Arecaceae } \\
\text { Piperaceae } \\
\text { Solanaceae }\end{array}$ & $\begin{array}{l}\text { Areca catechu } \mathrm{L} ., \text { Cocos nucifera } \mathrm{L} \text {. } \\
\text { Piper betle } \mathrm{L} \text {. } \\
\text { Nicotiana tabacum } \mathrm{L} \text {. }\end{array}$ \\
\hline
\end{tabular}

12 Manobo tribe rituals in Surigao del Sur, Philippines

Based on ritual observation among the Manobo tribe in the province, this cultural practice is strongly associated with their traditional knowledge and beliefs of their god, deities, and spirits. All foods prepared during rituals are cooked, shared, and eaten by members of the tribe. Ritual foods will be separated like a part of a chicken and a bowl of Oryza sativa, including the ritual plants A. catechu and $P$. betle to be taken home. These cultural practices and tribal activities are based on supernaturalism (Figure 2 AO). These rituals are often practiced on specific occasions and purposes as follows:

\section{Ritual for healing Binuyahan}

Binuyahan is culturally practiced for a sick person (Figure 2A-D). This ritual is categorized on how critically ill a person is into the following categories:

If the illness is mild "barato," the tribal healer will prepare the ripe fruit of $A$. catechu wrapped together with $P$. betle leaves, dried leaves of $N$. tabacum, and a bottle of local wine placed on a small platform. Then it will be followed by the shedding of blood from a red native chicken "sunoy." Then, the healer begins to pray. 
If the illness is severe, they will do the "mahal," the ritual outside the sick person's house. The Manobo healer "baylan" will prepare the ripe fruit of A. catechu "mama" wrapped together with $P$. betle "bujo" leaves, dried leaves of N. tabacum "tabako," and with a bottle of local wine "vino kulafu." These are all placed on a small platform decorated with an arc form of young leaves of $C$. nucifera L. "lubi." Then, the prayer of the healer begins.

If the illness is such severe "lala," the tribal healer will prepare the ripe fruit of $A$. catech $u$ wrapped together with $P$. betle leaves, dried leaves of $N$. tabacum, and a bottle of local wine placed on a small platform. The healer begins the prayer of the ritual, and while doing so, he will prepare a bowl that contains the $A$. catechu and $P$. betle then to be shed by the blood of a pig "baboy" (any color) placed above the head of the sick person. The ill person will be observed on the following day if they become better; therefore, it is an effect of enchantment. Otherwise, there is none.

If the illness is really severe, the "mawala sa kalibutan" or "gilamat" ritual is held inside the sick person's house. The healer will prepare the ripe fruit of $A$. catechu wrapped together with $P$. betle leaves and dried leaves of $N$. tabacum, placed on a small platform. When the ritual begins, the healer lays down beside the sick person and sings a Manobo ritual song, "tud-om," until the ill person falls asleep. The healer will sleep with the ill person and bring back the spirit or body parts through dreams or vision. The healing process will be successful if the healer can get around any parts of the ill person's body; otherwise, the sick person will die.

\section{Ritual for repentance Tampoda}

This ritual for repentance is being held outside the victim's house (Figure $2 \mathrm{E}$ ). The healer will prepare the ripe fruit of $A$. catechu wrapped together with $P$. betle leaves and dried leaves of $N$. tabacum, and uncooked rice Oryza sativa L. "bugas." This preparation is placed on a small platform decorated with an arc form of young leaves of $C$. nucifera and a minimum of $100 \mathrm{~kg}$ of the white pig as provided by the one who committed the crime. If a white pig is unavailable, the perpetrator will still search for a wild boar "baboy halas" or a wild chicken "katihan" instead. When all these are prepared, the plaintiff family of the member will stab the offered animal several times to forgive the perpetrator.

\section{Ritual for wedding Kumbiti}

Along with this ritual is the culture and tradition of the Manobo tribe in asking permission of a man to the parents of the woman he wants to marry, given that his courtship lasted for five years (Figure 2F). If the parents agree, they will prepare the ripe fruit of $A$. catechu wrapped together with $P$. betle leaves and dried leaves of $N$. tabacum, and a cooked rice $O$. sativa. These are placed on a small platform decorated with an arc form of young leaves of $C$. nucifera. The ethnic communities will be invited, and they will prepare five pigs to be sacrificed as ritual offerings to their deities. At the end of the ritual, the couple will squeeze the rice with their hands and eat it.

\section{Asking permission to enter the forest Mamaid}

Mamaid is a ritual to ask permission to enter the forest (Figure 2G). This ritual is being held inside or within the house. The ritual starts by preparing a white plate containing the ripe fruit of $A$. catechu wrapped together with $P$. betle leaves, $N$. tabacum, uncooked rice $O$. sativa, and other offerings like money (coins) or candies. The healer starts praying, and the three ritual plants are being poured by the blood of a native chicken (any color). This ritual is performed to ensure the security of the person while entering the forest and to return home safely.

\section{Thanksgiving for the harvest Panawagtawag}

This ritual has three stages: before cleaning the area or field, before planting, and before harvesting (Figure $2 \mathrm{H}$ ). The ceremony is held outside and starts by placing the ripe fruit of $A$. catechu wrapped together with $P$. betle leaves, dried leaves of $N$. tabacum, and a bottle of local wine on a small platform decorated with an arc form of young leaves of $C$. nucifera. This ritual is observed to safeguard the person or family while cleaning the area, to have bountiful crops before planting, and to give thanks for the good harvest and a successful season.

\section{House building ritual Pagmaan}

During the ritual, the healer will invoke prayers and offering to the mythical creatures and ask the gods to leave because people will reside in the area (Figure 2I). The healer prepared the ritual plants like the ripe fruit of $A$. catech $u$ wrapped together with $P$. betle leaves, dried leaves of $N$. tabacum, and a bottle of local wine on a small platform decorated with an arc form of young leaves of $C$. nucifera. The ritual is performed as an offering to the mythical creatures to exchange the place and safety.

\section{Ritual for barrier Pamebag}

This ritual is performed to hinder any illness or lousy spirit from coming in for peoples' safety (Figure 2J). It is believed that the offering serves as a wall or barrier for the community healthcare system. The healer, including the tribal community, prepares the ritual plants such as the ripe fruit of $A$. catechu wrapped together with $P$. betle leaves, dried leaves of $N$. tabacum, and uncooked $O$. sativa and with a bottle of local wine along with the food offerings across the road.

\section{Ritual for baptism Tagun-un}

Tagun-un is a ritual for the baptism of a child (Figure $2 \mathrm{~K})$. This ritual will be held inside the house. The healer prepared the ritual plants like the ripe fruit of A. catechu wrapped together with $P$. betle leaves, dried leaves of $N$. tabacum, and a bottle of local wine on a small platform decorated with an arc form of young leaves of $C$. nucifera. During the ritual, the healer starts praying that the child will live a healthy life, guided by their gods to do good and avoid evil.

\section{Ritual for forgiveness Boneh}

Boneh is a ritual for forgiveness (Figure 2L). This ritual will be held outside the house. The Manobo healer will 
prepare the ripe fruit of $A$. catechu wrapped together with $P$. betle leaves, uncooked $O$. sativa, and dried leaves of $N$. tabacum. These are placed in a small platform decorated with an arc form of young leaves of $C$. nucifera and a minimum of 100 kilograms (white pig) given by the one who committed the crime. Also, the one who committed the crime will provide anything that the victim wants, and when all these are ready, the ritual starts, the family of the member will stab the offered animal many times. Through this, the one who committed the crime will be forgiven.

\section{Ritual for full-moon festival Kahimonan}

All tribal communities are invited to celebrate the fullmoon festival (Figure 2M). The healer prepares the ripe fruit of $A$. catechu wrapped together with $P$. betle leaves and dried leaves of $N$. tabacum, and uncooked $O$. sativa placed in a small platform decorated with an arc form of young leaves of $C$. nucifera. The healer starts praying, and the four ritual plants are to be shed with the blood of a pig (any color). After the ritual, the celebration begins with the music of drums "gembe" and the singing of their ritual song "tud-om." Everybody will dance until morning. This ritual is done every month or during harvest time.

\section{Ritual for birth Limpasan}

Limpasan is a ritual for birth (Figure $2 \mathrm{~N}$ ). This ritual will be held inside the house. The healer prepared the ritual plants like the ripe fruit of $A$. catechu wrapped together with $P$. betle L. leaves and dried leaves of $N$. tabacum on a small platform decorated with an arc form of young leaves of $C$. nucifera. The healer starts the ritual with a chicken (any color) sacrificed, and blood will be shed near the mother's stomach. It is believed that the violence committed by the parents will be cleansed.

\section{Ritual for burial Uyagdok}

Uyagdok is a ritual for burial that will be held outside the house (Figure 2O). The ritual plants are prepared by the healer like the ripe fruit of $A$. catechu wrapped together with $P$. betle leaves, dried leaves of Nicotiana tabacum, and with a bottle of local wine and candles (any color) on a small platform decorated with an arc form of young leaves of $C$. nucifera. The healer starts praying, and the four ritual plants are to be shed with the blood of a native chicken (red) and try to call out a mythical creature, "abyan," to guide the spirit of the dead to their journey. The dead body will be buried at their burial ground within the ethnic community, and the healer will lead prayers.

\section{Characteristics of ritual plants}

Arecaceae family is represented with two species, while other families are composed of only one species. The CI index accounts for the number of informants and uses and the plant species' worth (Tardio and Pardo-de-Santayana 2008), making it a proficient tool to show which plant species have high-frequency usage. The plant families with high-frequency use were the Arecaceae, Piperaceae, and Solanaceae.

Figure 2 presents the habit of the ritual plants of the Manobo tribe. It shows that the tree and herb have the highest percentage $(37 \%)$, followed by the vine $(26 \%)$. According to Dapar et al. (2020a), the Manobo tribe depends mainly on plants because they believe that using plants in their rituals will strengthen their belief and aid their relationship with the environment. It becomes their way of giving back to nature by conserving their community plant resources.

The availability of the plants is categorized into two as common or rare depending on the commonality or abundance of species in the area (Figure 3). Two ritual plants were identified as 'common' $(60 \%)$ in the area, such as Cocos nucifera and Oryza sativa. Identified rare plants (40\%) were Areca catechu, Piper betle, and Nicotiana tabacum, as these plants can be obtained in the wild and mountain areas distant from their barangays (villages).

Figure 4 shows the percentage of plant parts used by the Manobo tribe in their rituals. Two fruits are being used (40\%) from A. catechu and O. sativa, while three leaves $(60 \%)$ are being used from $P$. betle, N. tabacum, and $C$. nucifera (young ones). Of all the plant parts used for rituals, the leaves are the most important and frequently utilized since leaves are easily accessible than other plant parts. The tribe believes that leaves are more valuable than any other part of the plant, essential for plant survival. Most of the Manobo ritual plants are obtained from the wild having three species $(60 \%)$, followed by a cultivated species $(20 \%)$, and a species obtained in both (20\%), as shown in Figure 5. The source of Manobo ritual plants is primarily wild, just like their medicinal plants, as documented by Dapar et al. (2020a).

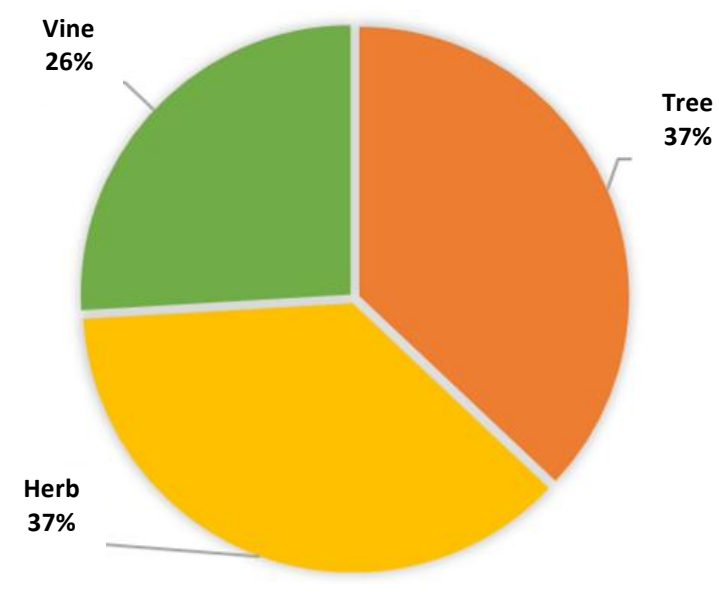

Figure 2. Percentage of the habit of the ritual plants 

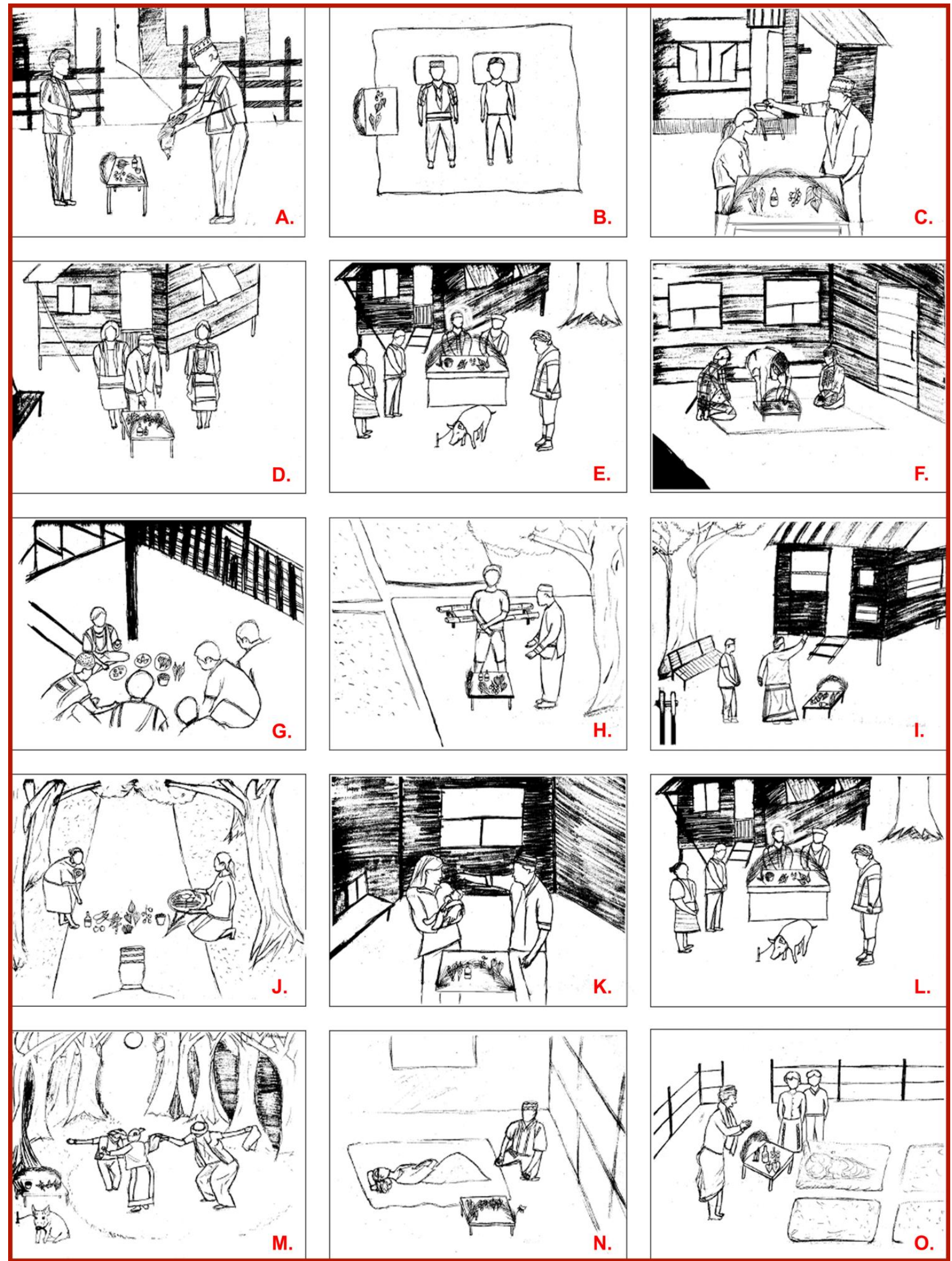

Figure 2. The 12 rituals of the Manobo tribe in Surigao del Sur, Philippines. "Binuyahan" ritual for healing: if the illness is mild "barato" (A); if the disease is highly severe "gilamat" (B); if the disease is severe "lala" (C) or "mahal" (D). Other rituals: for repentance "tampoda" (E); for the wedding "kumbiti" (F); for asking permission to enter the forest "mamaid" (G); for thanksgiving of harvest "panawagtawag" $(\mathrm{H})$; for building house "pagmaan" (I); for barrier "pamebag" (J); for baptism "tagun-un" (K); for forgiveness "boneh" (L); for the full-moon festival "kahimonan" (M); for birth "limpasan" $(\mathrm{N})$; and for burial "uyagdok" (O). Illustration by JKAM Jamera 


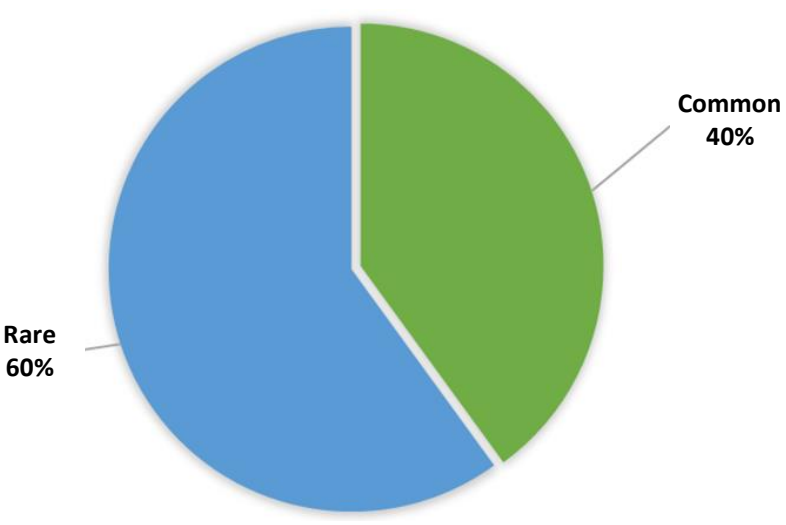

Figure 3. Percentage of the availability of the ritual plants

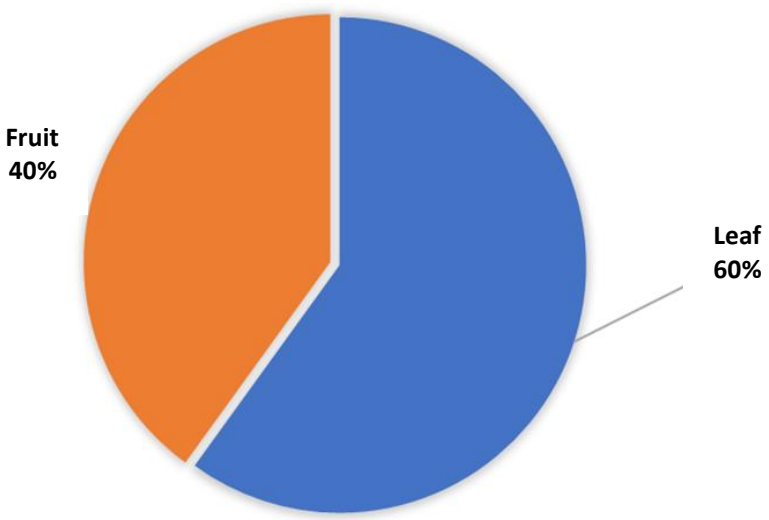

Figure 4. Percentage of plant part used in ritual

Figure 6 presents the percentage of the method of preparation practiced by Manobo based on their documented 12 rituals using most of the same plant species. Frequency showed that modes of preparation are distributed equally in percentage $(20 \%)$ such as dried, directly obtained, wrapped together with $P$. betle leaves and $A$. catechu fruit, while either cooked or raw encompass the remaining $20 \%$.

\section{Discussion}

All ritual plants were surveyed equally among the Manobo healers tasked to perform their rituals. Ritual plants are essential elements to ritual practices of the Manobo culture. For instance, ritual plants commonly used in both localities were Areca catechu L. "mama," Nicotiana tabacum L. "tabako," and Piper betle L. "bujo." The A. catechu is usually wrapped with $P$. betle and mixed a small amount of a pulverized shell "apog," that is believed in strengthening their teeth when Areca nut is being chewed.

Traditionally, chewing of areca nut is conventional in the eastern part of the world. The trend is observed commonly in Madagascar, South Asia, Southeast Asia, and

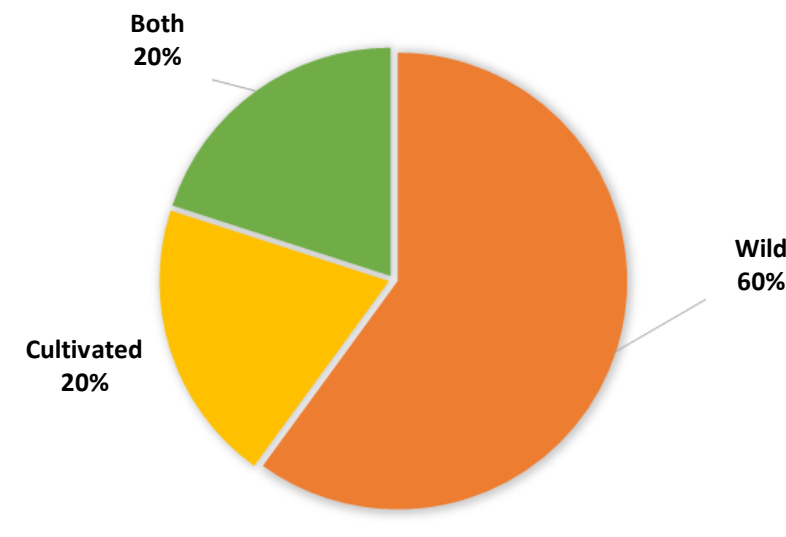

Figure 5. Percentage of plant part used in ritual

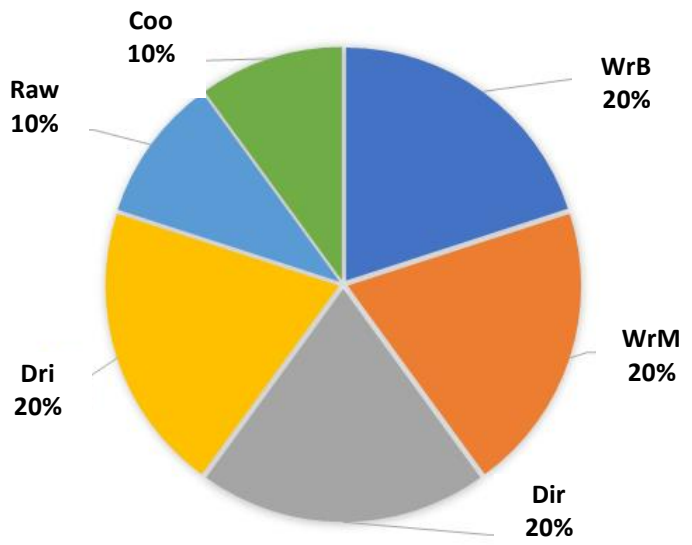

Figure 6. Percentage of the method of preparation practiced by the Manobo tribe in their rituals. Coo, cooked; Raw, uncooked; Dri, dried; Dir, directly obtained; WrB wrapped together with bujo leaves, and WrM wrapped together with "mama" fruit

the Solomon Islands (Irwanto and Irsyam 2020). A. catechu seed is traditionally chewed with betel leaf, P. betle, and lime. This cultural practice is evident in the study of Dapar et al. (2020b) in documenting the Manobo tribe of Agusan del Sur depicting the actual ritual of asking permission to enter the forest "Mamaid." In Central or Southern Mindanao, betel chewing is a ritualistic custom among the Maranao, Maguindanao, Bagobo, and Tausug groups (Valdez 2004). Indigenous rituals and cultural practices were often observed in remote and forested areas where the tribe is closely linked with their ancestral past (Molintas 2004).

Nowadays, traditional knowledge is gradually decreasing due to rapid urbanization, acculturation, and man's independence in the modern health care system (Dapar et al. 2020b, 2020c). However, the ritual and folk system still prevails in the rural communities. In their belief system, plants and humans have their spirit that should be taken good care of and value their presence in the environment.

Comparatively, the Surigao Manobo tribes from two villages, namely barangay Cabangahan and barangay Hinapuyan of Surigao del Sur, differ in their local ritual 
terms used. For instance, the ritual term "Panawagtag" in Hinapuyan is different in Cabangahan as they use the term "Uyagdok." However, "Uyagdok" is used as a burial ritual in Hinapuyan. The term "Binuyahan" is a ritual for healing in Hinapuyan but is called "Pasayloa" in Cabangahan. The processes and methods of their rituals are most likely the same but only differ in the applied local terms.

From the present study, it can be deduced that the Manobo tribe continues to rely on their traditional knowledge and ritual culture learned from their ancestors. However, modern society already highly influenced the Manobo tribes of surveyed barangays, including their educational system, healthcare system, and language used. Into the bargain, the Manobo pass their knowledge and culture to the next generation through oral tradition (Dapar et al. 2020c), like wearing their cultural costumes and even use of their native language in their territory. Documentation of ritual practices and benefits of plant species with biocultural importance among indigenous communities is essential for preserving culture and tradition. The indigenous knowledge, conservation practices, ecological understanding, and resource management are vital for future environmental management (UNESCO 2019). They serve critical roles in protecting their culture and indigenous territories (Dapar et al. 2020d, 2020e).

Manobo people believe that deities reside in their indigenous forests and live in their ancestral territories. This cultural belief is marked on the minds of the tribe with obedience and respect to avoid harm and destruction in their livelihoods and living. They continually conserve their plants for their regard for social, cultural, and religious purposes. The Manobo rituals, festivals, and other cultural practices are directly associated with their surroundings preserved religiously. The stigma of getting punished by their deities and forest spirits is instilled in their customs and tradition to obey and respect their gods and deities through prayers and making sacrifices and offerings.

Like other tribes, tribal folklore is directed in magicoreligious beliefs and taboos (Sharma and Pegu 2011). The continuation of the ritual practices has significant potential for natural resources conservation (Geng et al., 2017). Ritual plants are exciting studies in Philippines ethnobotany, which are an integral part of the culture and relationship of the people and plants (Dapar and Alejandro 2020). Therefore, this study documented the ritual practices and ritual-plant uses among the Manobo tribe of Surigao del Sur and its importance in the cultural knowledge on traditional ritual practices. Further documentation on ritual plants and practices of indigenous peoples should be further conducted to understand ritual plant knowledge, particularly its distribution and comparison within and among ethnic groups in the Philippines and other countries.

\section{ACKNOWLEDGEMENTS}

We are very thankful to the Manobo tribe in Surigao del Sur for their free Prior Informed Consent (PIC) and for generously sharing information on our documentation. The first author thanks RB Cerbito, FL Tejano, JCN Jamera, and SM Daitol for their assistance and support. The second author acknowledges LF Olowa and JJ Manubag for sharing their knowledge and expertise. The third author thanks the scholarship grant of the Department of Science and Technology - Accelerated Science and Technology Human Resource Development Program - National Science Consortium (DOST-ASTHRDP-NSC).

\section{REFERENCES}

Abdulaziz AA, Dapar MLG, Manting MME, Torres AJ, Aranas AT, Mindo RAR, Cabrido CK, Demayo CG. 2019. Qualitative evaluation of the antimicrobial, antioxidant, and medicinally important phytochemical constituents of the ethanolic extracts of the leaves of Gliricidia sepium (Jacq.). Pharmacophore 10: 72-83.

Abbink J. 1995. Medicinal and ritual plants of the Ethiopian Southwest: An account of recent research. Indigenous Knowledge and Development Monitor 3 (2): 6-8.

Añides JA, Dapar MLG, Aranas AT, Mindo RAR, Manting MME, Torres MAJ, Demayo CG. 2019. Phytochemical, antioxidant, and antimicrobial properties of the white variety of 'Sibujing' (Allium ampeloprasum). Pharmacophore 10: 1-12.

Pelser PB, Barcelona JF, Nickrent DL (eds). 2011 onwards. Co's Digital Flora of the Philippines. www.philippineplants.org.

Dapar MLG, Alejandro GJD. 2020. Ethnobotanical studies on indigenous communities in the Philippines: current status, challenges, recommendations, and future perspectives. J Complement Med Res 11 (1): 432-446. DOI: 10.5455/jcmr.2020.11.01.51.

Dapar MLG, Demayo CG. 2017. Folk medical uses of Lunas Lunasia amara Blanco by the Manobo people, traditional healers, and residents of Agusan del Sur, Philippines. Sci Int (Lahore) 29 (4): 823826.

Dapar MLG, Demayo CGD, Senarath WTPSK. 2018. Antimicrobial and cellular metabolic inhibitory properties of the ethanolic extract from the bark of 'Lunas-Bagon' (Lunasia sp.). Int J Pharm Sci Res 9: 8897. DOI: 10.13040/IJPSR.0975-8232.9(1).88-97.

Dapar MLG, Demayo CG, Meve U, Liede-Schumann S, Alejandro GJD. 2020a. Molecular confirmation, constituents, and cytotoxicity evaluation of two medicinal Piper species used by the Manobo tribe of Agusan del Sur. Philippines. Phytochem Lett 36: 24-31. DOI: 10.1016/j.phytol. 2020.01.017.

Dapar MLG, Alejandro GJD, Meve U, Liede-Schumann S. 2020 b. Quantitative ethnopharmacological documentation and molecular confirmation of medicinal plants used by the Manobo tribe of Agusan del Sur, Philippines. J Ethnobiol Ethnomed 16: 14. DOI: 10.1186/s13002-020-00363-7.

Dapar MLG, Meve U, Liede-Schumann S, Alejandro GJD. 2020c. Ethnomedicinal plants used to treat cuts and wounds by the Agusan Manobo of Sibagat, Agusan del Sur, Philippines. Ethnobot Res App 19: 1-18. DOI: 10.32859/era.19.31.1-18.

Dapar MLG, Alejandro GJD, Meve U, Liede-Schumann S. 2020d. Ethnomedicinal importance and conservation status of medicinal trees among indigenous communities in Esperanza, Agusan del Sur, Philippines. J Complement Med Res 11 (1): 59-71. DOI: 10.5455/jcmr.2020.11.01.08.

Dapar MLG, Meve U, Liede-Schumann S, Alejandro GJD. 2020e. Ethnomedicinal appraisal and conservation status of medicinal plants among the Manobo tribe of Bayugan City, Philippines. Biodiversitas 21(8):3843-3856. DOI: 10.13057/biodiv/d210854.

Dela Peña JF, Dapar MLG, Aranas AT, Mindo RAR, Cabrido CK, Torres MAJ, Manting MME, Demayo CG. 2019. Assessment of antimicrobial, antioxidant, and cytotoxic properties of the ethanolic extract from Dracontomelon dao (Blanco) Merr. \& Rolfe. Pharmacophore 10: 18-29.

De Jong R. 2010. The last tribes of Mindanao, the Manobo, river people of Cotabato. Things Asian. http://thingsasian.com/story/last-tribesmindanao-manobo-river-peoplecotabato.

Erawan TS, Alillah AN, Iskandar J. 2018. Ethnobotany of traditional rituals in the Karangwangi Village, Cianjur District, West Java, 
Indonesia. Asian J Ethnobiol. 1 (2): 53-60. DOI 10.13057/asianjethnobiol/y010201.

Felix MLE. 2004. Exploring the indigenous local governance of Manobo tribes in Mindanao. Phil J Pub Adm. 48: 125.

Galeano G. 2000. Forest use at the pacific coast of Chocó, Colombia: A quantitative approach. Econ Bot 54: 358-376. DOI 10.1007/BF02864787.

Geng Y, Hu G, Ranjitkar S, Shi Y, Zhang Y, Wang Y. 2017. The implications of ritual practices and ritual plant uses on nature conservation: a case study among the Naxi in Yunnan Province, Southwest China. J Ethnobiol Ethnomed 13: 58. DOI: 10.1186/s13002-017-0186-3.

Hariyadi B, Ticktin T. 2012. Uras: medicinal and ritual plants of Serampas, Jambi Indonesia. Ethnobot Res App 10: 133-149. 10.17348/era.10.0.133-149.

Irwanto RR, Irsyam ASD. 2020. Areca catechu L. Arecaceae. In: Franco F. (eds) Ethnobotany of the mountain regions of Southeast Asia Ethnobotany of Mountain Regions. Springer, Cham. DOI: 10.1007/978-3-030-14116-5_58-1.

Iskandar J, Iskandar BS. 2017. Various plants of traditional rituals: ethnobotanical research among The Baduy community. Biosaintifika 9 (1): 114-125. DOI: 10.15294/biosaintifika.v9i1.8117.

Nadayag J, Dapar MLG, Aranas AT, Mindo RAR, Cabrido CK, Manting MME, Torres AJ, Demayo CG. 2019. Qualitative assessment of the antimicrobial, antioxidant, and phytochemical properties of the ethanolic extracts of the inner bark of Atuna racemosa. Pharmacophore 10: 52-59

Pardo-de-Santayana M, Tardío J, Blanco E, Carvalho AM, Lastra JJ, Miguel ES, Morales R. 2007. Traditional knowledge of wild edible plants used in the northwest of the Iberian Peninsula (Spain and Portugal): a comparative study. J Ethnobiol Ethnomed. 3: 27. DOI: 10.1186/1746-4269-3-27.

Quiroz D, Sosef M, van Ande Tinde. 2016. Why ritual plant use has ethnopharmacological relevance. J Ethnopharmacol 188:48-56. https://doi.org/10.1016/j.jep.2016.05.006.

Sharma UK, Pegu S. 2011. Ethnobotany of religious and supernatural beliefs of the Missing tribes of Assam with special reference to the 'Dobur Uie.' J Ethnobiol Ethnomed 7: 16. DOI: 10.1186/1746-42697-16.

Tardío J, Pardo-de-Santayana M. 2008. Cultural importance indices: a comparative analysis based on the useful wild plants of Southern Cantabria (Northern Spain). Econ Bot 62: 24-39. DOI: 10.1007/s12231-007-9004-5.

UNESCO. 2019. Indigenous knowledge and biodiversity. https://en.unesco.org/links/biodiversity.

Uy IA, Dapar MLG, Aranas AT, Mindo RAR, Manting MME, Torres MAJ, Demayo CG. 2019. Qualitative assessment of the antimicrobial, antioxidant, phytochemical properties of the ethanolic extracts of the roots of Cocos nucifera L. Pharmacophore 10: 63-75.

Valdez CO. 2004. Betel chewing in the Philippines. http://www.lasieexotique.com/page/LasieExotique-mag_betel.html. 